\title{
EKSTRAKSI DAN IDENTIFIKASI METABOLIT SEKUNDER DARI ISOLAT AL6 SERTA POTENSINYA SEBAGAI ANTIBAKTERI TERHADAP Escherichia coli
}

\section{Extraction and Identification of Secondary Metabolites from AL6 Isolates and Its Potential as Antibacterial against Escherichia coli}

\author{
Alfian Syarifuddin ${ }^{1 *}$, Sodiq Kamal ${ }^{2}$, Fitriana Yuliastuti ${ }^{1}$, Missya Putri Kurnia Pradani ${ }^{1}$, \\ Ni Made Ayu Nila Septianingrum ${ }^{1}$ \\ 1Departemen Farmasi, Fakultas IImu Kesehatan, Universitas Muhammadiyah Magelang, \\ Jalan Mayjend Bambang Soegeng km 5, Mertoyudan 56172, Kabupaten Magelang, Jawa Tengah \\ ${ }^{2}$ Departemen Keperawatan, Fakultas Ilmu Kesehatan, Universitas Muhammadiyah Magelang, \\ Jalan Mayjend Bambang Soegeng km 5, Mertoyudan 56172, Kabupaten Magelang, Jawa Tengah \\ *Email: alfiansy@ummgl.ac.id
}

\begin{abstract}
Secondary metabolites in the form of antibiotics can be produced by rhizospheric bacteria. AL6 bacterial isolate, which is one of the bacterial isolates from the rhosphere of Saccarum officinarum $L$., is known to produce antibiotic compounds. This study aims to determine the activity of antibiotics from AL6 ethyl acetate extracts produced by AL6 bacterial isolates, to analyze the minimum inhibitory concentration (MIC) and the similarity of the active substances using GCMS. The ethyl acetate extract obtained was tested for MIC at 1.25\%, 2.5\%, 5.0\%, $10.0 \%, 20 \%$, and $40 \%$ concentrations. Detection of potential antibiotic spots was carried out using bioautographic thin layer chromatography (TLC). Compounds responsible for antibiotic activity were analyzed using GCMS. Minimum inhibitory levels obtained reached $2.5 \%$. The active spots responsible for antibiotic activity against Escherichia coli at Rf 0.94. Components detected using GCMS and suspected to be antibiotics include chloroform; ethane, 1,1dimethoxy-(CAS) dimethyl acetal; dan 1,3-dioxolane, 2-methoxymethyl-2,4,5-trimethyl.
\end{abstract}

Keywords: AL6 bacterial isolate, antibiotic, Escherichia coli, GCMS, MIC

\begin{abstract}
ABSTRAK
Metabolit sekunder berupa antibiotik dapat diproduksi oleh bakteri rizosfer. Isolat bakteri AL6, salah satu isolat bakteri dari rizosfer Saccarum officinarum L., diketahui dapat menghasilkan senyawa antibiotik. Penelitian ini bertujuan mengetahui aktivitas antibiotik dari ekstrak etil asetat antibiotik AL6 yang dihasilkan isolat bakteri AL6, menganalisis kadar hambat minimum (KHM), serta kemiripan zat aktif menggunakan GCMS. Ekstrak etil asetat yang diperoleh diuji KHM-nya pada konsentrasi 1,25\%, 2,5\%, 5,0\%, 10,0\%, 20\%, dan 40\%. Deteksi bercak yang berpotensi sebagai antibiotik dilakukan menggunakan kromatografi lapis tipis (KLT) bioautografi. Senyawa yang berperan dalam aktivitas antibiotik dianalisis menggunakan GCMS. Kadar hambat minimal yang diperoleh mencapai 2,5\%. Hasil uji KLT bioautografi memperlihatkan bercak aktif sebagai antibiotik terhadap Escherichia coli pada Rf 0,94. Komponen senyawa yang terdeteksi menggunakan GCMS dan diduga sebagai antibiotik antara lain chloroform; ethane, 1,1-dimethoxy-(CAS) dimethyl acetal; dan 1,3-dioxolane, 2 methoxymethyl-2,4,5-trimethyl.
\end{abstract}

Kata Kunci: antibiotik, Escherichia coli, GCMS, isolat bakteri AL6, KHM 


\section{PENDAHULUAN}

Senyawa antimikroba diproduksi oleh berbagai mikroorganisme, antara lain bakteri, jamur, dan juga tanaman. Salah satu bakteri yang dapat memproduksi antibiotik adalah actinomycetes (Gebreyohannes et al. 2013). Actinomycetes adalah jenis bakteri gram positif berfilamen (Nanjwade et al. 2010). Penelitian yang dilakukan oleh Apsari et al. (2019) tentang pengujian senyawa aktif dari Actinomycetes yang aktif menghambat pertumbuhan bakteri penyebab infeksi saluran kemih, yaitu bakteri Escherichia coli, Citrobacter braakii, Acinetobacter calcoaceticus, and Klebsiella pneumoniae. Ekstrak dianalisis senyawa aktifnya menggunakan gas chromatography-mass spectrometry (GCMS) dihasilkan senyawa aktif, yaitu propane, 1,2-dichloro, nhexadecanoic acid, and carbonochloridic acid, 2-chloroethyl ester.

Ekstraksi dan pemurnian serta elusidasi
struktur metabolit sekunder dari Streptomyces coelicoflavus BC 01 yang dilakukan Raghava Rao et al. (2017) dihasilkan nilai kadar hambat minimal masing-masing isolat, yaitu BC 01_C1, BC01_C2, BC01_03 terhadap S. aureus (MTCC 3160) adalah $25 \mu \mathrm{g} \mathrm{mL} \mathrm{m}^{-1}, 12,5 \mu \mathrm{g}$

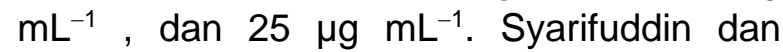
Sulistyani (2018) melakukan uji kadar hambat minimum (KHM) fraksi teraktif dari senyawa antibiotik KP13 terhadap bakteri Escherichia coli. Hasil penelitian tersebut menghasilkan nilai KHM 5\%. Nanjwade et al. (2010) melakukan pengujian $\mathrm{KHM}$ isolat $\mathrm{A} 4$ terhadap beberapa bakteri uji. Dari hasil penelitian tersebut diketahui bahwa pada bakteri gram positif Staphylococcus aureus dan Bacillus subtilis didapatkan hasil uji KHM masingmasing sebesar 125 dan $100 \mu \mathrm{g} \mathrm{mL}^{-1}$. Selain itu pada bakteri E. coli, Pseudomonas aeruginosa, dan Klebsiella pneumoniae didapatkan nilai KHM pada bakteri uji masing-masing 125, 100, dan $100 \mu \mathrm{g} \mathrm{mL}^{-1}$. Pada jamur uji Candida albicans dan Saccharomyces cerevisiae dihasilkan nilai KHM 125 dan $125 \mu \mathrm{g} \mathrm{mL}{ }^{-1}$. Narwanti dan Sulistyani (2015) melakukan uji kromatografi lapis tipis (KLT) bioautografi 5 isolat bakteri, yaitu T19, T24, T25, T37 and T41 terhadap bakteri E. coli dan Staphylococcus aureus.
Hasil penelitian tersebut menghasilkan spot aktif hanya pada isolat T25 yang berpotensi sebagai antibiotik yang ditinjau pada nilai $\mathrm{Rf}$ 0,9 terhadap bakteri Staphylococcus aureus.

KLT bioautografi menggunakan eluen kloroform:metanol (3:7) dilakukan Selvameenal et al. (2009) terhadap esktrak etilasetat dari metabolit sekunder rizosfer Rajasthan sejak 2006. Ekstrak tersebut berpotensi sebagai antibiotik pada $\mathrm{Rf} 0,768$ pada MRSA, VRSA, Escherichia coli, dan Klebsiella sp. KLT bioautografi yang dilakukan oleh Syarifuddin et al. (2019) dengan fase gerak kloroform:etil asetat:metanol $(4: 1: 0,5, \mathrm{v} / \mathrm{v} / \mathrm{v})$ isolat AL6 menghasilkan bercak aktif sebagai antibiotik pada nilai $\mathrm{Rf} 0,78$. Hasil analisis senyawa aktif yang berpotensi sebagai antibiotik menggunakan GCMS tersebut menghasilkan senyawa cycloheptatriene dan tetrahydropyran.

Penelitian ini dilakukan untuk mengetahui aktivitas antibiotik ekstrak etil asetat isolat AL6 yang diisolasi dari rizosfer Saccharum officinarum dengan menganalisis nilai kadar hambat minimumnya dan melakukan uji KLT bioautografi terhadap bakteri uji $E$. coli. Pengujian untuk mendapatkan senyawa yang bertanggung jawab sebagai antibiotik terhadap bakteri $E$. coli dengan menggunakan instrumen GCMS. Penelitian ini bermanfaat untuk mengetahui kadar minimal dari isolat AL6 yang masih dapat berpotensi sebagai antibiotik terhadap pertumbuhan bakteri $E$. coli. KHM tersebut dapat digunakan untuk penentuan pengujian lanjutan fraksi dari ekstrak etil asetat. Nilai Rf yang dihasilkan dalam uji KLT bioautografi ini dapat digunakan untuk penelitian berikutnya dalam pemurnian senyawa yang dihasilkan oleh isolat AL6, antara lain KLT preparatif dan kromatografi kolom.

\section{BAHAN DAN METODE}

\section{Tempat dan waktu penelitian}

Laboratorium Farmasi Universitas Muhammadiyah Magelang dan Laboratorium Penelitian Terpadu Farmasi Universitas Ahmad Dahlan, bulan Januari - Maret 2019

\section{Bahan}

Starch nutrient broth (SNB), medium Mueller Hinton, aquades, etil asetat, DMSO $10 \%$, metanol. 


\section{Preparasi kultur}

Isolat AL6 hasil isolasi dari rizosfer tanah tebu di Madugondo, Desa Sitimulyo, Kecamatan Piyungan, Kabupaten Bantul, Provinsi Daerah Istimewa Yogyakarta (749'57.9"S $\left.110^{\circ} 26^{\prime} 01.1 " E\right)$, sebanyak $5 \mathrm{~mL}$ dimasukkan ke dalam Erlenmeyer yang berisi $50 \mathrm{~mL}$ medium SNB steril (Wang et al. 2010). Kultur bertingkat dilakukan dengan perbandingan antara starter dengan medium kultur (1:10), yaitu $50 \mathrm{~mL}$ kultur ke dalam 500 $\mathrm{mL}$ medium SNB steril dan inkubasi pada suhu kamar (Khucharoenphaisan et al. 2012), disertai agitasi selama 14 hari menggunakan magnetic stirrer (Ahsan et al. 2017).

\section{Ekstraksi antibiotik}

Kultur uji yang sudah diinkubasi selama 14 hari disaring menggunakan corong Buchner, kemudian dipekatkan pada suhu $50^{\circ} \mathrm{C}$. Filtrat diekstraksi menggunakan corong pisah dengan pelarut etil asetat $(1: 1 \mathrm{v} / \mathrm{v})$ sampai warna hasil ekstraksi sama dengan pelarut semula. Fase air dan fase etil asetat dipisahkan. Fase etil asetat diambil dan zat aktif dipisahkan dari pelarut etil asetat dengan cara diuapkan menggunakan rotary evaporator, dilanjutkan dengan diuapkan di lemari asam sampai didapatkan ekstrak etil asetat (Hemashenpagam 2011).

\section{Uji aktivitas antibiotik dengan uji sumuran}

Ekstrak ditimbang sebanyak $40 \mathrm{mg}$ dan dilarutkan kembali dengan metanol hingga $100 \mu \mathrm{L}$. Mikroorganisme yang digunakan untuk uji aktivitas yaitu E. coli. Medium uji menggunakan medium Mueller Hinton steril yang telah digores bakteri uji. Lubang sumuran diisi dengan ekstrak etil asetat $20 \mu \mathrm{L}$ dan diinkubasi pada suhu $37^{\circ} \mathrm{C}$ selama $18-24$ jam. Aktivitas antibiotik dari ekstrak etil asetat AL6 ditunjukkan dengan adanya zona bening di sekitar lubang sumuran (Alimuddin et al. 2011).

\section{Penentuan nilai KHM}

Ekstrak ditimbang dan dibuat seri kadar $1,25 \%, 2,5 \%$, $5 \%$, $10 \%$, 20\%, dan $40 \%$ sebanyak $50 \mu \mathrm{L}$. Setiap paper blank disc diisi dengan larutan sampel dengan masingmasing seri kadar sebanyak $20 \mu \mathrm{L}$, lalu dibiarkan selama 2 jam, dan diinkubasi pada suhu $37^{\circ} \mathrm{C}$ selama $18-24$ jam (Rai et al.
2016). Aktivitas dari fraksi ekstrak etil asetat AL6 ditunjukkan dengan adanya zona bening di sekitar lubang sumuran (Alimuddin e al. 2011).

\section{Kromatografi lapis tipis}

Kromatografi lapis tipis ekstrak dilakukan pada plat KLT dengan bantuan pipa kapiler $5 \mu \mathrm{L}$ dengan konsentrasi $20 \%$. Fase diam yang digunakan adalah gel silika F254 sedangkan fase geraknya adalah kloroform:etil asetat:metanol $(4: 1: 0,5, \mathrm{v} / \mathrm{v} / \mathrm{v})$ (Syarifuddin dan Sulistyani 2019). Sebelum memasukkan plat KLT ke dalam chamber, fase gerak (eluen) dibiarkan hingga jenuh di dalam chamber. Untuk melihat pola pemisahannya, kromatogram tersebut dideteksi dengan lampu UV $254 \mathrm{~nm}$ dan 366 $\mathrm{nm}$, kemudian ditentukan nilai Rf-nya.

\section{Analisis bioautografi}

Ekstrak etil asetat pada plat yang telah dielusi diletakkan pada media Mueller Hinton yang telah ditanami bakteri $E$. coli dibiarkan selama 30 menit dan plat dilepas. Sampel uji diinkubasi pada suhu 37으 selama 18-24 jam. Potensi antibiotik pada bercak yang dihasilkan ditentukan dengan melihat zona bening pada media, dan menghitung $\mathrm{Rf}$ bercak yang berpotensi sebagai antibiotik tersebut (Salni et al. 2011).

\section{Pembuatan suspensi bakteri E. Coli}

Stok bakteri sebanyak $100 \mu \mathrm{L}$ dimasukkan ke dalam $1 \mathrm{~mL}$ Brain Heart Infusion (BHI) steril, diinkubasi pada suhu 37으 selama 18-24 jam. Suspensi bakteri yang dihasilkan lalu diambil $100 \mu \mathrm{L}$ untuk dimasukkan ke dalam $\mathrm{BHI} 1 \mathrm{~mL}$, diinkubasi selama 3-5 jam di dalam inkubator. Sebanyak $100 \mu \mathrm{L}$ bakteri diencerkan dengan $\mathrm{NaCl}$ 0,9\% sampai kekeruhan sesuai dengan standard McFarland $1,5 \times 10^{8} \mathrm{CFU} \mathrm{\textrm {mL } ^ { - 1 }}$ (Mulyadi dan Sulistyani 2013).

\section{HASIL DAN PEMBAHASAN}

Kultur bertingkat bertujuan untuk mengkondisikan isolat AL6 memasuki fase log (eksponensial). Perbedaan waktu fase pertumbuhan dapat terjadi karena actinomycetes mempunyai waktu pertumbuhan yang sangat variatif (Wang et al. 2010). Inkubasi selama 14 hari menghasilkan perubahan warna cairan kultur. 


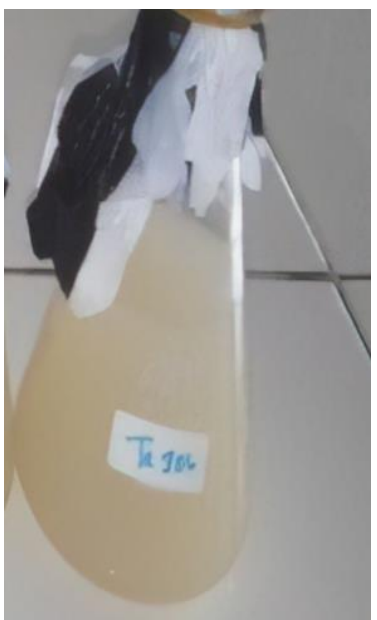

Hari ke-1

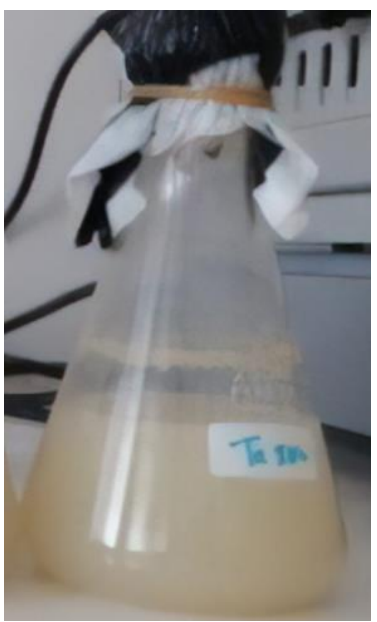

Hari ke-10

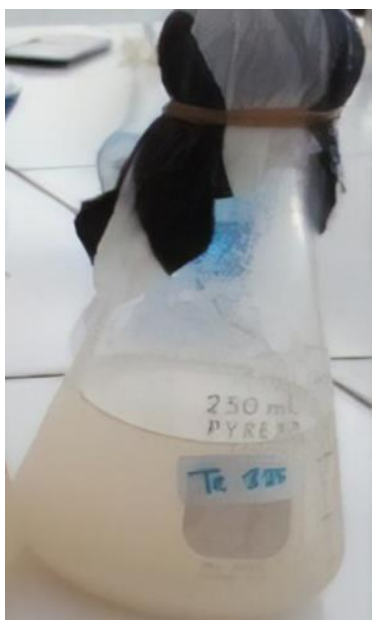

Hari ke-5

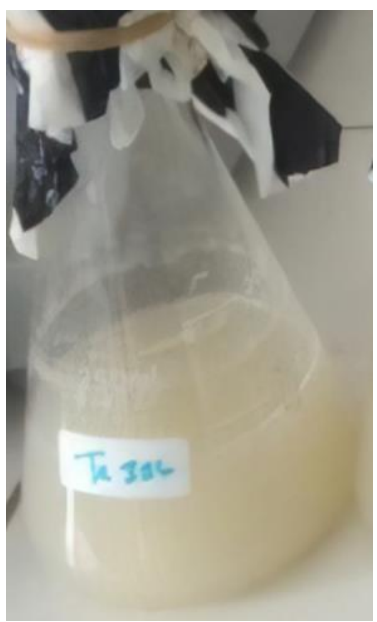

Hari ke-14
Gambar 1. Perubahan warna pada kultur uji

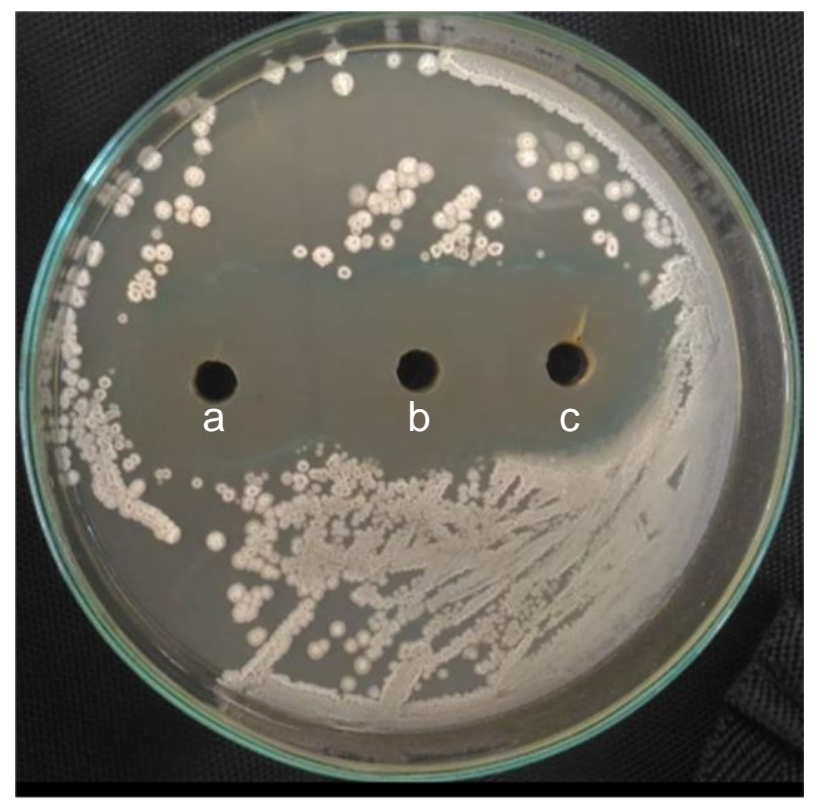

Tabel 1. Hasil pengamatan perubahan warna kultur uji

\begin{tabular}{cccc}
\hline Hari ke- & Warna & Hari ke- & Warna \\
\hline 1 & putih bening & 8 & coklat muda \\
2 & putih bening & 9 & coklat muda \\
3 & putih bening & 10 & coklat muda \\
4 & coklat muda & 11 & coklat + \\
5 & coklat muda & 12 & coklat + \\
6 & coklat muda & 13 & coklat + \\
7 & coklat muda & 14 & coklat + \\
\hline
\end{tabular}

Perubahan warna yang terjadi selama waktu inkubasi menunjukkan adanya produksi pigmen dari hasil metabolisme. Perubahan warna yang terjadi pada cairan kultur isolat AL6 disebabkan karena isolat AL6 mengeluarkan pigmen warna khas actinomycetes (Gambar 1). Perubahan warna pigmen selama inkubasi isolat AL6 ditunjukkan pada Tabel 1. Terdapat varian warna hasil metabolisme sekunder dari isolat actinomycetes (Mohamed et al. 2017).

Kultur sebanyak 1 liter yang telah diinkubasi selama 14 hari disaring dan filtrat diekstraksi menggunakan etil asetat $(1: 1, \mathrm{v} / \mathrm{v})$ (Singh et al. 2014). Hasil ekstraksi menghasilkan rendemen 5,33 g. Ekstraksi metabolit sekunder Streptomyces sp. dan Exserohilum rostratum yang ditumbuhkan pada medium optimal MEB mendapatkan randemen masing-masing pada fermentasi minggu ke-10, yaitu 11,9 gram dan 24,0 gram (Chasanah et al. 2012).

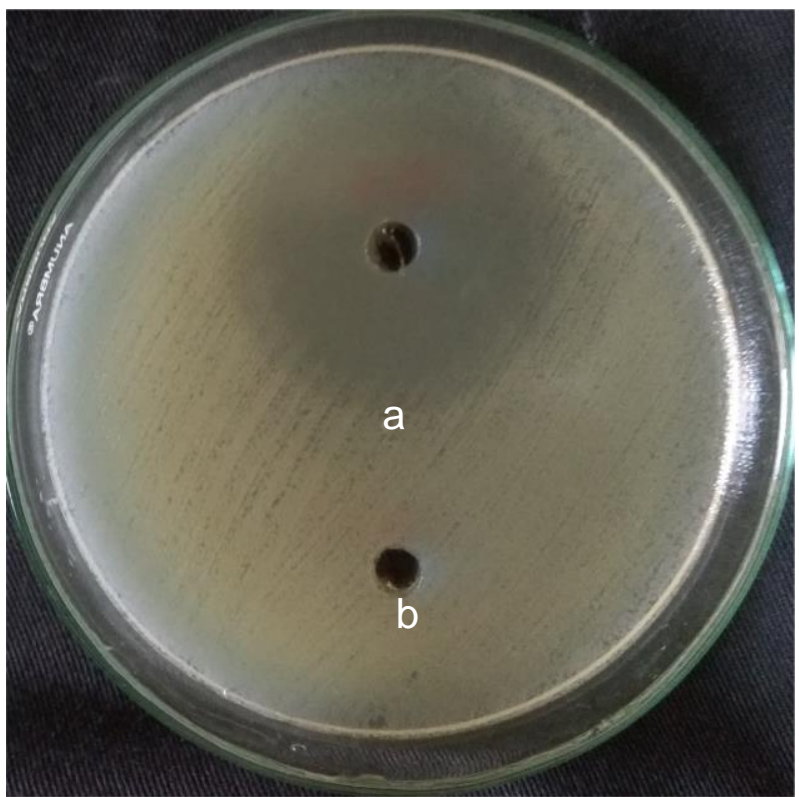

Gambar 2. Uji aktivitas ekstrak etil asetat isolat AL6 dengan konsentrasi $40 \%$ dan kontrol +(kloramfenikol 1\%) kontrol DMSO 10\% Gambar kiri: a) ekstrak I 40\%, b) ekstrak II 40\%, c) ekstrak III 40\%. Gambar kanan: a) kontrol $+($ kloramfenikol 1\%), b) kontrol - (DMSO 10\%) 
Aktivitas antibiotik ekstrak etil asetat isolat AL6 dengan konsentrasi $40 \%$ terhadap bakteri $E$. coli menghasilkan zona hambat di sekitar lubang sumuran dengan nilai rata-rata diameter zona hambat sebesar 31,33 $\pm 1,15$ $\mathrm{mm}$, seperti pada Gambar 2 dan Tabel 2. Ekstrak etil asetat dari metabolit AL6 tergolong dalam potensi kuat. Potensi antibiotik terbagi menjadi 3 golongan, yaitu golongan lemah dengan rentang diameter zona hambat 7-15 $\mathrm{mm}$, golongan sedang dengan rentang diameter $16-25 \mathrm{~mm}$, dan

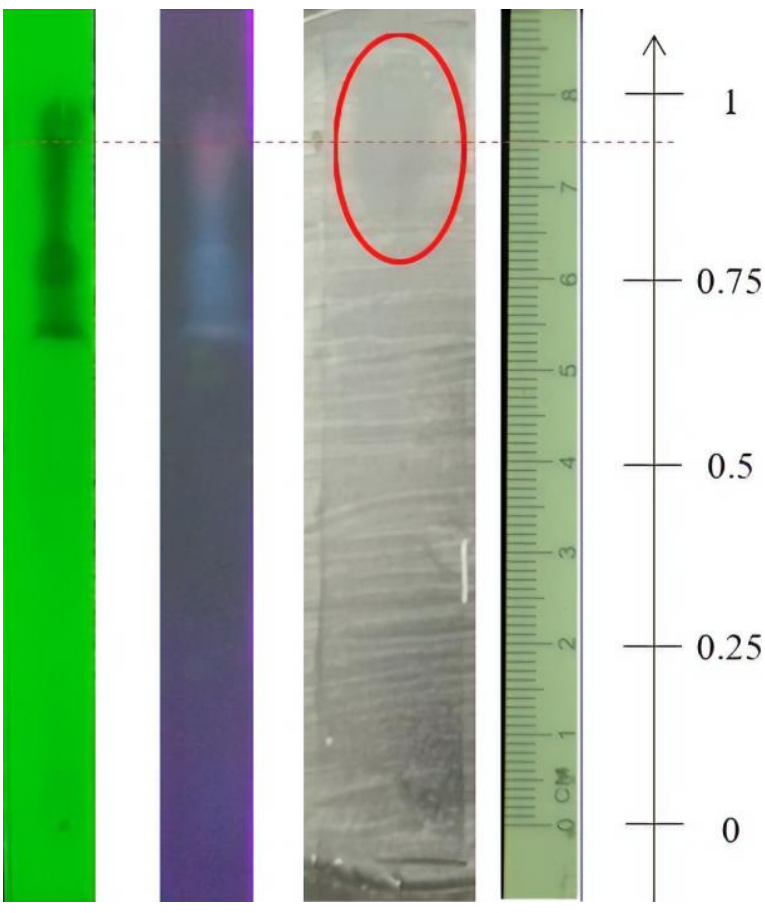

Gambar 3. Hasil uji bioautografi kelompol fraksi teraktif terhadap E. coli. (lingkaran merah adalah daerah zona hambat) tergolong kuat dengan diameter zona hambat lebih dari $25 \mathrm{~mm}$ (Retnowati et al. 2018). Kontrol negatif yang digunakan adalah DMSO 10\% (Hassan 2014). Kontrol positif yang digunakan adalah kloramfenikol 1\% (Utomo et al. 2018). Analisis statistik pada sampel ekstrak etil asetat isolat AL6 40\% terdistribusi normal tetapi tidak homogen pada uji homogenitas. Oleh karena itu ekstrak etilasetat AL6 40\% tersebut diuji non parametrik dengan dilakukan analisis menggunakan uji Kruskal-Wallis. Berdasarkan hasil analisis, kontrol positif memperlihatkan aktivitas antibiotik tertinggi dibandingkan dengan sampel dan kontrol negatif tetapi pada uji Mann Whitney, ekstrak etil asetat AL6 dengan konsentrasi 40\% berbeda bermakna terhadap kontrol negatif DMSO 10\%.

Kadar terkecil ekstrak etil asetat AL6 yang dapat menghambat pertumbuhan bakteri $E$. coli diuji dengan menentukan nilai KHM (Fauziyya et al. 2017). Hasil pengujian tersebut menghasilkan nilai KHM ekstrak etil asetat terhadap bakteri E. coli dengan konsentrasi $2,5 \%$ dan mempunyai rata-rata diameter zona hambat sebesar 6,93 $\pm 0,11$ $\mathrm{mm}$ yang ditunjukkan pada Tabel 3 . Penelitian lainnya oleh Salim et al. (2017), menghasilkan nilai KHM ekstrak isolat FA9 sebesar $0,51 \mu \mathrm{g} \mathrm{mL}^{-1}$ pada $E$. coli dan $K$. pneumonia, selain itu $1,02 \mu \mathrm{g} \mathrm{mL}^{-1}$ terhadap $E$. faecalis dan $M$. luteus. Nilai $\mathrm{KHM}$ isolat AL6 atau kemampuan menghambat bakteri E. coli mempunyai potensi sebagai antibiotik dengan nilai $\mathrm{KHM} 2,5 \% \quad(\mathrm{~b} / \mathrm{v})$. Analisis

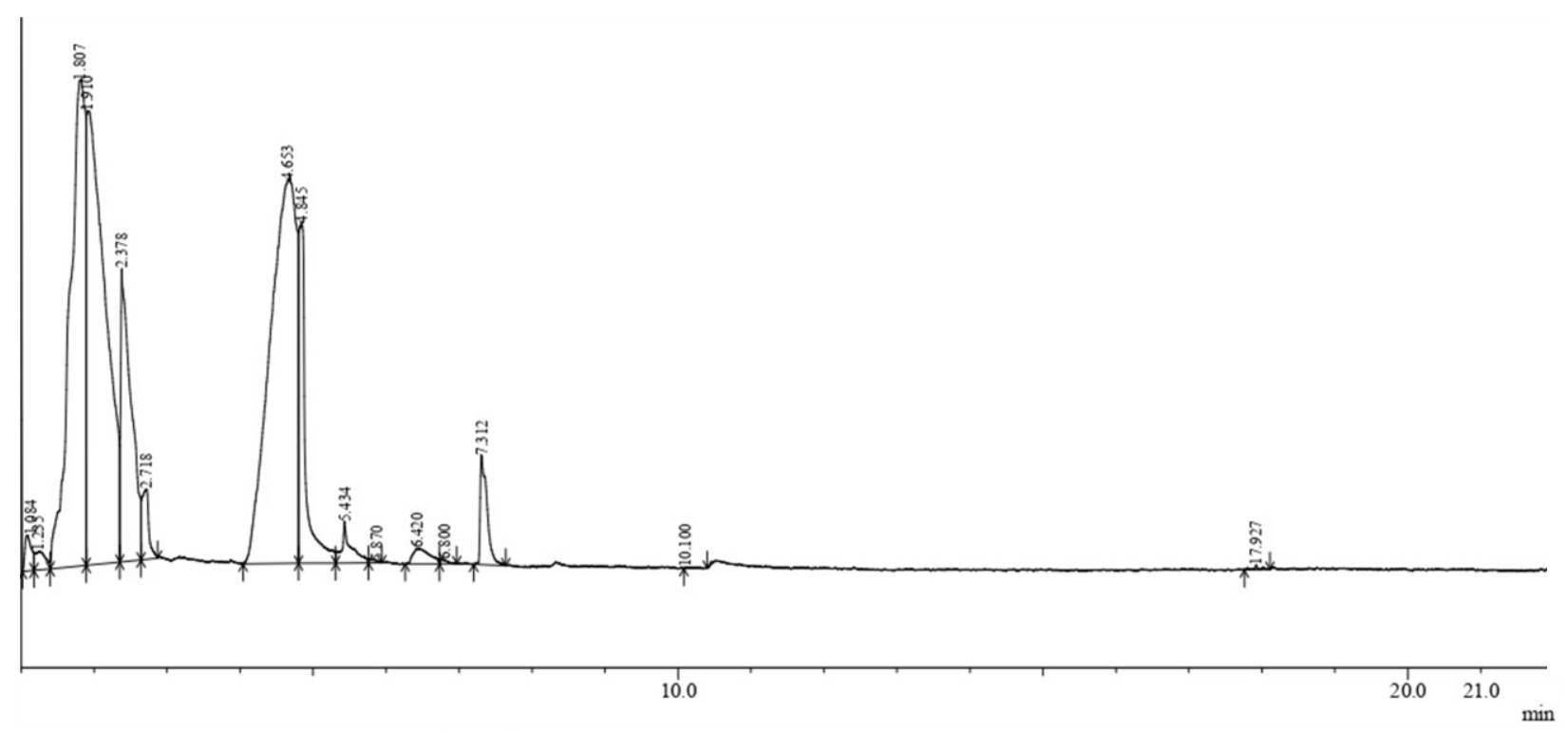

Gambar 4. Profil kromatogram GCMS isolat AL6 
Tabel 2. Uji aktivitas ekstrak etil asetat AL6 pada bakteri E. coli

\begin{tabular}{cccc}
\hline $\begin{array}{c}\text { Konsentrasi } \\
(\%)\end{array}$ & Replikasi & $\begin{array}{c}\text { Zona } \\
\text { Hambat } \\
(\mathrm{mm})\end{array}$ & $\begin{array}{c}\text { Rata-Rata } \\
\text { Zona Hambat } \\
(\mathrm{mm}) \pm \text { SD }\end{array}$ \\
\hline $40 \%$ & 2 & 32,00 & \\
& 3 & 30,00 & $31,33 \pm 1,15$ \\
\hline \multirow{2}{*}{$\begin{array}{c}\text { Kloramfenikol } \\
1 \%\end{array}$} & 1 & 35,30 & \\
\hline & 3 & 39,50 & $37,06 \pm 2,17$ \\
\hline DMSO 10\% & 1 & 36,40 & \\
& 2 & 6,00 & \\
& 3 & 6,00 & $6,00 \pm 0,00$ \\
\hline
\end{tabular}

Keterangan: *signifikan ( $p$ value $<0,05)$ terhadap kontrol negatif

Tabel 3. Rata-rata zona hambat uji kadar hambat minimum terhadap bakteri $E$. coli

\begin{tabular}{|c|c|c|c|}
\hline $\begin{array}{c}\text { Konsentrasi } \\
(\%)\end{array}$ & Replikasi & $\begin{array}{c}\text { Zona } \\
\text { Hambat } \\
(\mathrm{mm})\end{array}$ & $\begin{array}{c}\text { Rata-Rata } \\
\text { Zona Hambat } \\
(\mathrm{mm}) \pm \mathrm{SD}\end{array}$ \\
\hline \multirow{3}{*}{40} & 1 & 32,00 & \multirow{3}{*}{$31,33 \pm 1,15$} \\
\hline & 2 & 30,00 & \\
\hline & 3 & 32,00 & \\
\hline \multirow{3}{*}{20} & 1 & 28,00 & \multirow{3}{*}{$26,00 \pm 5,29$} \\
\hline & 2 & 30,00 & \\
\hline & 3 & 20,00 & \\
\hline \multirow{3}{*}{10} & 1 & 14,00 & \multirow{3}{*}{$13,67 \pm 1,52$} \\
\hline & 2 & 15,00 & \\
\hline & 3 & 12,00 & \\
\hline \multirow{3}{*}{5} & 1 & 6,00 & \multirow{3}{*}{$6,00 \pm 0,00$} \\
\hline & 2 & 6,00 & \\
\hline & 3 & 6,00 & \\
\hline \multirow{3}{*}{2,5} & 1 & 7,00 & \multirow{3}{*}{$6,93 \pm 0,11^{*}$} \\
\hline & 2 & 7,00 & \\
\hline & 3 & 6,80 & \\
\hline \multirow{3}{*}{1,25} & 1 & 6,00 & \multirow{3}{*}{$6,00 \pm 0,00$} \\
\hline & 2 & 6,00 & \\
\hline & 3 & 6,00 & \\
\hline \multirow{3}{*}{$\begin{array}{l}\text { Sontrol negatif } \\
\text { (DMSO 10\%) }\end{array}$} & 1 & 6,00 & \multirow{3}{*}{$6,00 \pm 0,00$} \\
\hline & 2 & 6,00 & \\
\hline & 3 & 6,00 & \\
\hline \multirow{3}{*}{$\begin{array}{l}\text { Kontrol positif } \\
\text { (kloram- } \\
\text { fenikol 1\%) }\end{array}$} & 1 & 35,30 & \multirow{3}{*}{$37,06 \pm 2,17$} \\
\hline & 2 & 39,50 & \\
\hline & 3 & 36,40 & \\
\hline
\end{tabular}

Keterangan: *signifikan $(p$ value $<0,05)$ terhadap kontrol negatif statistiknya menunjukkan bahwa diameter zona hambat untuk pengujian KHM dengan analisis pada penambahan konsentrasi $1,25 \%$ mempunyai nilai yang sama terhadap kontrol negatif, sedangkan pada penambahan konsentrasi 25\% mempunyai nilai hasil analisis lebih tinggi dibandingkan dengan kontrol negatif. Dengan demikian, diperoleh hasil nilai KHM isolat AL6 sebesar $2,5 \%$.

Penggunaan metode KLT bioautofgrafi digunakan untuk penapisan senyawa antibiotik dengan meninjau bercak pada nilai Rf yang menghasilkan zona bening pada media (Narwanti dan Sulistyani 2015). Metode bioautografi yang digunakan pada penelitian ini adalah bioautografi kontak, yaitu dilakukan dengan meletakkan lempeng kromatogram hasil elusi di atas medium Mueller Hinton yang sudah ditanami bakteri E. coli. Lempeng KLT dipastikan kontak atau menempel dengan baik pada permukaan medium sehingga senyawa aktif dapat berdifusi secara optimal pada medium Mueller Hinton yang sudah ditanami bakteri E. coli. Hal ini dilakukan dengan cara membiarkan lempeng KLT menempel pada media uji selama 30 menit, dan mengamati zona jernih yang terbentuk setelah diinkubasi pada suhu $37^{\circ} \mathrm{C}$ selama $18-24$ jam (Sulistyani dan Akbar 2014). Hasil percobaan ditunjukkan pada Gambar 3. Pada uji KLT bioautografi ekstrak etil asetat isolat AL6 didapatkan senyawa pada bercak (spot) yang berpotensi sebagai antibiotik, yaitu pada nilai Rf 0,94 terhadap pertumbuhan bakteri $E$. coli. Penelitian dilakukan oleh Syarifuddin dan Sulistyani (2019), mengenai karakterisasi senyawa antibiotik yang dihasilkan oleh isolat KP13 menggunakan metode KLT semprot dan densitometri. Penelitian tersebut menghasilkan bercak dengan puncak tertinggi dengan nilai $\mathrm{Rf} 0,78$ pada kromatogram densitometri dengan panjang gelombang $210 \mathrm{~nm}$. Senyawa yang dihasilkan tersebut mengandung gugus utama terpenoid, alkaloid, dan karbonil. Dalam penelitian ini, kandungan senyawa antibiotik dalam ekstrak etil asetat yang sudah diuji menggunakan KLT bioautografi, dan sudah menghasilkan bercak aktif pada nilai $\mathrm{Rf} 0,94$, dianalisis secara kualitatif menggunakan GCMS. Hasil analisis GCMS dapat diamati pada Tabel 4 dan Gambar 4. Komponen senyawa yang teridentifikasi 
Tabel 4. Data GC-MS ekstrak etil asetat isolat AL6

\begin{tabular}{|c|c|c|c|}
\hline $\begin{array}{l}\text { Waktu Retensi } \\
\text { (menit) }\end{array}$ & Senyawa & Kelimpahan (\%) & Kemiripan (\%) \\
\hline 1,084 & Methyl 15-acetylhydroxypalmitate & 1,59 & 82 \\
\hline 1,235 & Hi-oleic safflower oil (CAS) Safflower oil & 0,82 & 72 \\
\hline 1,807 & Tetradeuterovalproic acid & 21,54 & 83 \\
\hline 1,910 & Phenylethyl tiglate 2 & 20,15 & 75 \\
\hline 2,378 & 2-Ethenyl-1,1-difluorocyclopropane & 12,98 & 77 \\
\hline 2,718 & Chloroform & 3,10 & 97 \\
\hline 4,653 & Ethane, 1,1-dimethoxy- (CAS) Dimethylacetal & 16,99 & 91 \\
\hline 4,845 & Ethane, 1,1-dimethoxy- (CAS) Dimethylacetal & 15,08 & 89 \\
\hline 5,434 & $\begin{array}{l}\text { 2-Propanol, 1,1'-oxybis- (CAS) } \\
\text { Dipropylene glycol }\end{array}$ & 1,75 & 90 \\
\hline 5,870 & $\begin{array}{c}\text { 1,2,4-Cyclohexanetriol, } \\
\text { (1.alpha.,2.alpha.,4.beta.)- (CAS) } \\
\text { 1,Cis-2,trans-4-cyclohexanetriol }\end{array}$ & 0,10 & 51 \\
\hline 6,420 & (R)-[1-deuterium]cadaverine dihydrochloride & 0,67 & 89 \\
\hline 6,800 & $\begin{array}{c}\text { Cyclopropanecarbonic acid,-2-phenyl, ethyl } \\
\text { ester (Z-) }\end{array}$ & 0,17 & 53 \\
\hline 7,312 & $\begin{array}{c}\text { 1,3-Dioxolane, } 2 \text {-methoxymethyl-2,4,5- } \\
\text { trimethyl }\end{array}$ & 4,85 & 97 \\
\hline 10,100 & $\begin{array}{c}\text { 11-Methoxy-16- } \\
\text { de(methoxycarbonyl)gambirtannine }\end{array}$ & 0,05 & 41 \\
\hline 17,927 & Dihydroxy-5,6-dihydrouracil & 0,19 & 88 \\
\hline
\end{tabular}

menggunakan GCMS dengan similarity index lebih dari $90 \%$ dengan database antara lain chloroform; ethane, 1,1-dimethoxy- (CAS) dimethyl acetal, dan 1,3-dioxolane, 2methoxymethyl-2,4,5-trimethyl. Konstituen utama sendiri atau dalam kombinasi dengan konstituen minor mungkin bertanggung jawab atas aktivitas antibakteri.

\section{KESIMPULAN}

Ekstrak etil asetat isolat bakteri AL6 mempunyai potensi antibiotik kuat, dan bercak aktif hasil uji bioautografi terdapat pada $\mathrm{Rf}$ 0,94 dengan senyawa dominan chloroform; ethane; 1,1-dimethoxy-(CAS) dimethyl acetal, dan 1,3-dioxolane, 2methoxymethyl-2,4,5-trimethyl. Perlu dilakukan penelitian lanjutan sampai memperoleh senyawa antibiotik baru.

\section{UCAPAN TERIMA KASIH}

Terima kasih kepada Universitas Muhammadiyah Magelang yang telah mendanai penelitian ini dan Laboratorium
Farmasi Universitas Muhammadiyah Magelang yang telah memfasilitasi alat penelitian.

\section{DAFTAR PUSTAKA}

Alimuddin, Widada J, Asmara W, Mustofa (2011) Antifungal production of a strain of Actinomycetes spp. isolated from the rhizosphere of cajuput plant: Selection and detection of exhibiting activity against tested fungi. Indones $\mathrm{J}$ Biotechnol 16:1-10. doi: 10.22146/ijbiotech.7829

Ahsan T, Chen J, Wu Y, Irfan M, Shafi J (2017) Screening, identification, optimization of fermentation conditions, and extraction of secondary metabolites for the biocontrol of Rhizoctonia solani AG-3. Biotechnol Biotechnol Equip 31:9198. doi: 10.1080/13102818.2016.1259016

Apsari PP, Budiarti S, Wahyudi AT (2019) Actinomycetes of rhizosphere soil producing antibacterial compounds 
against urinary tract infection bacteria. Biodiversitas J Biol Divers 20:12591265. doi: $10.13057 /$ biodiv/d200504

Chasanah E, Noor NM, Risjani Y, Dewi AS (2012) Aktivitas Antibakteri Dan Antioksidan Ekstrak Streptomyces sp. dan Exserohilum rostratum yang Dikultivasi Pada Tiga Jenis Medium Pertumbuhan. J Pascapanen Bioteknol Kelaut Perikan 7:39. doi: 10.15578/jpbkp.v7i1.67

Fauziyya R, Nurani LH, Sulistyani N (2017) antibacterial compound identification of cayenne pepper leaf extract (Capsicum frutescens L.) against Klebsiella pneumoniae and cell leakage mechanism. Maj Obat Tradis 22:166. doi: 10.22146/mot.31550

Gebreyohannes G, Moges F, Sahile S, Raja $N$ (2013) Isolation and characterization of potential antibiotic producing actinomycetes from water and sediments of Lake Tana, Ethiopia. Asian Pac J Trop Biomed 3:426-435. doi: 10.1016/S22211691(13)60092-1

Hassan AS (2014) The antibacterial activity of dimethyl sulfoxide (DMSO) with and without of some ligand complexes of the transitional metal ions of ethyl coumarin against bacteria isolate from burn and wound infection. J Nat Sci Res 4:106. doi: 10.13140/RG.2.2.36692.40321

Hemashenpagam N (2011) Purification of secondary metabolites from soil actinomycetes. Int $\mathrm{J}$ Microbiol Res 3:148-156. doi: 10.9735/09755276.3.3.148-156

Khucharoenphaisan K, Sripairoj N, Sinma K (2012) Isolation and identification of actinomycetes from termite's gut against human pathogen. Asian $\mathrm{J}$ Anim Vet Adv 7:68-73. doi: 10.3923/ajava.2012.68.73

Mohamed H, Miloud B, Zohra F, GarcíaArenzana JM, Veloso A, RodríguezCouto S (2017) Isolation and characterization of actinobacteria from Algerian sahara soils with antimicrobial activities. Int $\mathrm{J}$ Mol Cell Med 6:109-120

Mulyadi, Sulistyani N (2013) Aktivitas cairan kultur 12 isolat actinomycetes terhadap bakteri resisten. $\mathrm{J}$ Kesehat
Masy J Public Health 7:89-96. doi: 10.12928/kesmas.v7i2.1043

Nanjwade B, Chandrashekhara S, Goudanavar P, Shamarez A, Manvi F (2010) Production of antibiotics from soil-isolated actinomycetes and evaluation of their antimicrobial activities. Trop J Pharm Res 9:373377. doi: 10.4314/tjpr.v9i4.58933

Narwanti I, Sulistyani N (2015) TLCbioautography profile of ethyl acetate extract of 5 bacteria isolated from Ficus carica $\mathrm{L}$ rhizosphere. Int $\mathrm{J}$ Public Health Sci IJPHS 4:81-87. doi: 10.11591/.v4i2.4716

Raghava Rao KV, Mani P, Satyanarayana B, Raghava Rao T (2017) Purification and structural elucidation of three bioactive compounds isolated from Streptomyces coelicoflavus BC 01 and their biological activity. 3 Biotech 7:1-12. doi: 10.1007/s13205-0160581-9

Rai M, Bhattarai N, Dhungel N, Mandal PK (2016) Isolation of antibiotic producing Actinomycetes from soil of Kathmandu valley and assessment of their antimicrobial activities. Int $\mathrm{J}$ Microbiol Allied Sci 2:22-26

Retnowati Y, Moeljopawiro S, Djohan TS, Soetarto ES (2018) Antimicrobial activities of actinomycete isolates from rhizospheric soils in different mangrove forests of Torosiaje, Gorontalo, Indonesia. Biodiversitas 19:2196-2203. doi: 10.13057/biodiv/d190627

Salim FM, Sharmili SA, Anbumalarmathi J, Umamaheswari K (2017) Isolation, molecular characterization and identification of antibiotic producing actinomycetes from soil samples. J Appl Pharm Sci 7:069-075. doi: 10.7324/JAPS.2017.70909

Selvameenal L, Radhakrishnan $M$, Balagurunathan R (2009) Antibiotic pigment from desert soil actinomycetes; biological activity, purification and chemical screening. Indian J Pharm Sci 71:499-504. doi: 10.4103/0250-474X.58174

Singh LS, Sharma H, Talukdar NC (2014) Production of potent antimicrobial agent by actinomycete, Streptomyces sannanensis strain SU118 isolated 
from phoomdi in Loktak Lake of Manipur, India. BMC Microbiol 14:1-13. doi: 10.1186/s12866-0140278-3

Sulistyani N, Akbar AN (2014) Aktivitas isolat actinomycetes dari rumput laut (Eucheuma cottonii) sebagai penghasil antibiotik terhadap Staphylococcus aureus dan Escherichia coli. J IImu Kefarmasian Indones 12:1-9

Syarifuddin A, Sulistyani N (2018) Activity of antibiotic bacterial isolate $\mathrm{kp} 13$ and cell leakage analysis of Escherichia coli bacteria. J Ilmu Kefarmasian Indones 16:137-144. doi: 10.35814/jifi.v16i2.529

Syarifuddin A, Sulistyani N (2019) Karakterisasi fraksi teraktif senyawa antibiotik isolat kp 13 dengan metode densitometri dan klt-semprot. J IIm Ibnu Sina 4:156-166. doi: $10.36387 /$ jiis.v4i1.263
Syarifuddin A, Sulistyani N, Kintoko (2019) Profil KLT-bioautografi dan densitometri fraksi teraktif (isolat kp13) dari bakteri rizosfer kayu putih (Melaleucaleucadendron L.). J Farm Sains Prakt 5:21-25. doi: 10.31603/pharmacy.v5i1.2291

Utomo SB, Fujiyanti M, Lestari WP, Mulyani $S$ (2018) Antibacterial activity test of the C-4-methoxy phenylcalix[4]resorcinarene compound modified by hexadecyltrimethylammoniumbromide against Staphylococcus aureus and Escherichia coli bacteria. J Kim Pendidik Kim 3:201. doi: 10.20961/jkpk.v3i3.22742

Wang X, Huang L, Kang Z, Buchenauer H, Gao X (2010) Optimization of the fermentation process of actinomycete strain Hhs.015 ${ }^{\top}$. J Biomed Biotechnol 2010:1-10. doi: 